\title{
Moderate ethanol supply inhibits both glycogen synthesis and glycogenolysis in the perfused and isolated rat liver
}

\author{
M. C. Beauvieux ${ }^{1}$, P. Couzigou ${ }^{2}$, H. Roumes ${ }^{1}$, V. Rigalleau ${ }^{3}$, H. Gin ${ }^{3}$ and J. L. Gallis ${ }^{1}$ \\ ${ }^{1}$ RMSB UMR5536 CNRS-Université Bordeaux 2, Bordeaux, France, ${ }^{2}$ Hépato-alcoologie Hôpital Haut-Lévêque, Pessac, \\ France and ${ }^{3}$ Nutrition-diabétologie Hôpital Haut-Lévêque, Pessac, France
}

In isolated and perfused rat liver a positive glucose-dependent linear correlation between the net fluxes (Fn) of ATP and glycogen (Glg) has been found only in presence of insulin (Ins; Fn(Glg) $=72.5 \mathrm{Fn}(\mathrm{ATP})+172$ ); this result indicates that Ins can control the Glg store via energy metabolism ${ }^{(1)}$. Any change in this relationship in the presence of a substrate could then indicate a variation in insulin sensitivity. In the presence of a moderate ethanol $(\mathrm{EtOH})$ supply $(10 \mathrm{~mm})$ the slope of the correlation is 4 -fold higher $(284.5 \mathrm{Fn}(\mathrm{ATP})+2848)$, suggesting that for the same change in the consumption Fn of ATP Glg consumption is lower. Thus, the unidirectional hepatic fluxes (synthesis and lysis) of Glg were investigated in the presence of $10 \mathrm{mM}-\mathrm{EtOH}$.

Male Wistar rats $(100 \mathrm{~g})$ were fasted for $48 \mathrm{~h}$ in order to deplete the liver Glg store. Livers were then perfused with an isotonic buffer $\left(5 \mathrm{ml} / \mathrm{min}\right.$ per g; $\left.37^{\circ} \mathrm{C} ; \mathrm{O}_{2}-\mathrm{CO}_{2}, 95: 5(\mathrm{v} / \mathrm{v})\right)$ containing $30 \mathrm{~mm}$-glucose (enriched with $20 \%\left[1-{ }^{13} \mathrm{C}\right]$ glucose $)+\mathrm{Ins}(120 \mathrm{mIU} / \mathrm{l})+2 \mathrm{mM}-$ fructose to induce $\mathrm{Glg}$ synthesis. In a second step $\left[{ }^{13} \mathrm{C}\right]$ glucose was replaced by $30 \mathrm{~mm}$-glucose to investigate glycogenolysis. EtOH $(10 \mathrm{~mm})$ was added either in the Glg synthesis or the glycogenolysis phase ( $n 3$ for each dataset). The change in the Glg content was monitored by ${ }^{13} \mathrm{C}$ NMR (Brucker DPX400, 9.4T; Brucker, Bremen, Germany); since ATP is consumed for Glg synthesis, its hepatic content was measured by ${ }^{31} \mathrm{P}$ NMR.

The $48 \mathrm{~h}$ fasting induced a dramatic decrease in liver Glg content $(-99 \%)$. In the Glg synthesis study perfusion with $\left[{ }^{13} \mathrm{C}\right] \mathrm{gluco}-$ $\mathrm{se}+$ fructose induced an increase in the liver $\left[{ }^{13} \mathrm{C}\right] \mathrm{Glg}$ content (synthesis rate $2.4(\mathrm{SE} 0.2) \mu \mathrm{mol} / \mathrm{h}$ per g)), followed after $25 \pm 5 \mathrm{~min}$ by a decreased rate $(0.66$ (SE 0.07) $\mu \mathrm{mol} / \mathrm{h}$ per g; within $30 \mathrm{~min})$. After the addition of EtOH at $25 \mathrm{~min}$ of the incorporation phase a plateau of $\left[{ }^{13} \mathrm{C}\right]$ Glg content was observed, suggesting (a) inhibition of Glg synthesis or (b) an increase in glycogenolysis.

In the glycogenolysis study replacement of $\left[{ }^{13} \mathrm{C}\right]$ glucose with $30 \mathrm{~mm}$-glucose resulted in a decrease in $\left[{ }^{13} \mathrm{C}\right] \mathrm{Glg}(-0.69(\mathrm{SE} 0.08) \mu \mathrm{mol} / \mathrm{h}$ per $\mathrm{g}$ ) indicating glycogenolysis. The subsequent addition of EtOH reduced glycogenolysis $(-0.09$ (SE 0.01$) \mu \mathrm{mol} / \mathrm{h}$ per $\mathrm{g}$ ).

A moderate EtOH supply in presence of Ins inhibits both hepatic Glg synthesis and glycogenolysis.

1. Baillet-Blanco L, Beauvieux MC, Gin H, Rigalleau V \& Gallis JL (2005) Nutr Metab 2, 32-41. 